\title{
Strategi Pengembangan Agrowisata Melalui Pendekatan Quantitative Strategic Planning Matrix (QSPM)
}

\author{
Nelly Nur Azizaha, Farida Rahmawati ${ }^{\text {b* }}$ \\ ${ }^{a, b}$ Universitas Negeri Malang, Jalan Semarang No.5, Malang 65145, Indonesia \\ ${ }^{1}$ nellyna333@gmail.com; ${ }^{2 *}$ farida.rahmawati.fe@um.ac.id
}

Article history:

Submitted: May 20, 2020

Reviewed: June 8, 2020

Accepted: June 18, 2020

Published: June 30, 2020

Keywords:

Kata kunci: Strategi Pengembangan Pariwisata, Potensi Ekonomi Lokal, Perekonomian Masyarakat.

Salah satu agrowisata yang terdapat di Kota Blitar yaitu Agrowisata Belimbing Karangsari yang terletak di Kelurahan Karangsari. Di kelurahan ini memiliki potensi ekonomi lokal tanaman belimbing, karena besarnya potensi tersebut akhirnya dimanfaatkan sebagai agrowisata. Agrowisata ini menjadi sumber perekonomian bagi masyarakat setempat oleh karena itu agrowisata ini harus dikembangkan dengan strategi yang tepat. Tujuan dari penelitian ini adalah untuk menganalisis faktor internal dan eksternal yang dapat mempengaruhi pengembangan Agrowisata Belimbing Karangsari serta mengidentifikasi strategi yang tepat untuk mengembangkannya dalam rangka meningkatkan perekonomian masyarakat. Penelitian ini menggunakan metode penelitian kualitatif deskriptif menggunakan analisis SWOT. Berdasarkan hasil penelitian dapat disimpulkan bahwa kekuatan internal utama Agrowisata Belimbing Karangsari adalah aspek sarana dan prasarana yang memadahi sedangkan kelemahan internalnya adalah kurangnya kebersihan dan mahalnya harga belimbing. Faktor peluang eksternal utamanya adalah adanya dukungan dari pemerintah dan terkenalnya buah belimbing yang berasal dari Blitar sedangkan ancaman eksternalnya adalah pohon belimbing yang hanya berbuah 3 tahun sekali. Hasil analisis IE menunjukkan bahwa Agrowisata Belimbing Karangsari berada pada kuadran II yang tepat untuk menerapkan strategi stability. Hasil analisis SWOT menghasilkan 14 alternatif strategi. Strategi yang menjadi prioritas utama berdasarkan analisis QSPM adalah strategi menyediakan fasilitas petik buah yang memadahi agar dapat bersaing dengan tempat wisata lain.

Copyright (C) 2019 Politeknik Negeri Samarinda. All rights reserved.

\section{Pendahuluan}

Jawa Timur merupakan daerah yang memiliki potensi pariwisata dan telah dikunjungi banyak orang baik dalam negeri maupun luar negeri. Yang mejadi salah satu daya tarik bagi wisatawan untuk berkunjung adalah potensi yang dimiliki oleh daerah tersebut. Salah satu daerah yang memiliki potensi tersebut adalah Kota Blitar. Menurut
BPS (2017) Kota Blitar masuk ke dalam kategori kota terkecil di Jawa Timur yaitu dengan luas $32,57 \mathrm{~km}^{2}$. Kota Blitar merupakan salah satu kota yang tengah giat mengembangkan pariwisata berbasis potensi ekonomi lokal.

Dengan diberlakukannya UU No. 32 Tahun 2004 tentang Pemerintah Daerah maka setiap daerah harus melaksanakan otonomi daerah untuk mengembangkan 
potensinya, begitu pula dengan Kota Blitar. Otonomi daerah menuntut pemerintah daerah Kota Blitar untuk mampu meningkatkan potensi yang ada di dalamnya dengan tujuan untuk meningkatkan perekonomian masyarakat serta peningkatan peran serta masyarakat sebagai pemain kunci dalam kegiatan ekonomi. Kota Blitar memiliki potensi ekonomi lokal yang berbasis pertanian yaitu berupa buah belimbing tepatnya di Kelurahan Karangsari.

Dahulu secara turun-temurun di Kelurahan Karangsari setiap warganya diwajibkan untuk menanam pohon belimbing di lahan yang kosong. Sehingga sampai saat ini seluruh warga Karangsari memiliki pohon belimbing baik hanya beberapa pohon disekitar rumah maupun di kebun. Sehingga sebagian besar warga Karangsari mengandalkan pertanian belimbing untuk memenuhi kebutuhan hidupnya. Saat ini jumlah pohon belimbing di Kelurahan Karangsari telah mencapai 30.000 pohon.

Hampir keseluruhan produksi buah belimbing di Pulau Jawa dipasok oleh Kota Blitar, dan sebagian belimbing di Kota Blitar merupakan hasil produksi dari Kelurahan Karangsari. Peningkatan produksi buah belimbing paling banyak ada di tahun 2014 sampai 2015 yang pada saat itu merupakan awal dikembangkannya Agrowisata Belimbing Karangsari di kota Blitar. Berikut merupakan jumlah produksi di Kota Blitar dan Kelurahan Karangsari tahun 2012 2016.

Tabel 1. Produksi Belimbing Kota Blitar dan Kelurahan Karangsari Tahun 20122017

\begin{tabular}{ccc}
\hline Tahun & $\begin{array}{c}\text { Kota Blitar } \\
\text { (kuintal) }\end{array}$ & $\begin{array}{c}\text { Kelurahan } \\
\text { Karangsari } \\
\text { (kuintal) }\end{array}$ \\
\hline 2013 & 5024,81 & 3770,36 \\
\hline 2014 & 5230,09 & 3892,00 \\
\hline 2015 & 6210,72 & 4621,75 \\
\hline 2016 & 6537,60 & 4865,00 \\
\hline 2017 & 6748,82 & 5023,11 \\
\hline
\end{tabular}

Sumber: BPS (2017)

Dari tahun 2012 sampai dengan tahun 2017 produksi buah belimbing di Kota Blitar maupun di Kelurahan Karangsari terus mengalami peningkatan. Peningkatan jumlah produksi ini juga didasarkan atas naiknya permintaan buah belimbing dari konsumen sehingga petani belimbing diharuskan untuk menambah jumlah pohon dan tingkat produksinya.

Buah belimbing dari Karangsari ini dinamakan Belimbing Karangsari Merah yang dikembangkan oleh GAPOKTAN Margo Mulyo. Buahnya berbeda dengan buah Belimbing di daerah lain, yaitu memiliki buah yang besar, berwarna kuning kemerahan dan memiliki kadar air yang tinggi serta memiliki rasa yang manis, menurut beberapa petani disana, apabila buah belimbing karangsari merah ini ditanam di luar Karangsari maka rasa dan bentuk buahnya pun akan berbeda. Buah belimbing yang dihasilkan sudah disertifikasi oleh Menteri Pertanian menurut Surat Keputusan No.483/Kpts/LB 240/8/2004, ditetapkan sebagai varietas unggul.

Diantara kebun belimbing milik warga, ada satu lahan milik Pemerintah Kota Blitar yang merupakan tanah bengkok seluas 5ha yang ditanami buah belimbing. Kebun tersebut disewakan kepada warga Karangsari yang ingin memiliki pohon belimbing. Perkebunan ini diresmikan oleh pemerintah daerah pada tahun 2007 dan dijadikan sebagai agrowisata lahan itulah yang dijadikan sebagai Agrowisata Belimbing Karangsari.

Berdasarkan penelitian pendahuluan yang dilakukan oleh peneliti sebagian besar petani belimbing di Agrowisata Belimbing Karangsari hanya bergantung pada pertanian belimbingnya dan tidak memiliki mata pencaharian lain, sehingga perekonomian petani belimbing tergantung kepada wisatawan yang datang ke agro. Agrowisata Belimbing Karangsari bukan hanya berdampak positif bagi petani belimbing saja tetapi juga berdampak kepada masyarakat sekitar. Perekonomian masyarakat sekitar juga meningkat karena memiliki mata pencaharian baru seperti pedagang belimbing, pedagang oleh-oleh, pemandu wisata, tukang parkir dll.

Mengingat besarnya potensi ekonomi yang dimiliki, diperlukan strategi yang tepat untuk mengembangkan Agrowisata Belimbing Karangsari salah satunya dengan meningkatkan jumlah wisatwan yang berkunjung. Untuk merumuskan strategi yang tepat, peneliti memerlukan pendapat 
beberapa wisatawan tentang Agrowisata Belimbing Karangsari dengan cara menyebar angket. Oleh karena itu peneliti mengangkat judul Strategi Pengembangan Pariwisata Berbasis Potensi Ekonomi Lokal dalam Rangka Meningkatkan Perekonomian Masyarakat (Studi Pada: Agrowisata Belimbing Karangsari Blitar). Judul tersebut diangkat oleh peneliti dengan tujuan untuk mengidentifikasi strategi yang tepat dalam mengembangkan Agrowisata Belimbing Karangsari agar dapat meningkatkan perekonomian masyarakat, mengingat besarnya potensi ekonomi lokal yang dimiliki.

\section{Review Tinjauan Pustaka}

Pengembangan pariwisata meruapakan usaha untuk mengembangkan objek wisata agar menarik minat wisatawan untuk mengunjunginya. Sederhananya, dengan pengembangan wisata maka akan lebih banyak wisatawan yang datang bekunjung, tinggal lebih lama dan melakukan aktivitas ekonomi (konsumsi) di kawasan wisatawan tersebut. Dengan demikian, bisa meningkatkan pendapatan daerah tersebut. Pengembangan pariwisata sebagai suatu industri secara ideal harus berlandaskan pada empat prinsip dasar, sebagaimana dikemukakan (Sobari dalam Anindita, 2015), yaitu :

1. Kelangsungan ekologi, yaitu bahwa pengembangan pariwisata harus menjamin terciptanya pemeliharaan dan proteksi terhadap Sumber Daya alam yang menjadi daya tarik pariwisata, seperti lingkungan laut, hutan, pantai, danau, dan sungai.

2. Kelangsungan kehidupan sosial dan budaya, yaitu bahwa pengembangan pariwisata harus mampu meningkatkan peran masyarakat dalam pengawasan tata kehidupan melalui sistem nilai yang dianut masyarakat setempat sebagai identitas masyarakat tersebut.

3. Kelangsungan ekonomi, yaitu bahwa pengembangan pariwisata harus dapat menciptakan kesempatan kerja bagi semua pihak untuk terlibat dalam aktivitas ekonomi melalui suatu sistem ekonomi yang sehat dan kompetitif.
4. Memperbaiki dan meningkatkan kualitas hidup masyarakat setempat melalui pemberian kesempatan kepada mereka untuk terlibat dalam pengembangan pariwisata.

Dengan demikian, pengembangan pariwisata (yang berkelanjutan) perlu didukung dengan perencanaan yang matang dan harus mencerminkan tiga dimensi kepentingan, yaitu industri pariwisata, daya dukung lingkungan (sumber daya alam), dan masyarakat setempat dengan sasaran untuk peningkatan kualitas hidup.

\section{Metodologi Penelitian}

Penelitian ini dilakukan di Kawasan Agrowisata Belimbing Karangsari yang terletak di Jl. Cemara No. 303, Karangsari, Sukorejo, Kota Blitar, Jawa Timur. Pemilihan tempat penelitian ini dilakukan secara sengaja (purposive). Penelitian ini menggunakan metode kualitatif deskriptif dengan pendekatan studi kasus. Metode deskriptif kualitatif dilakukan agar peneliti dapat mengetahui dan mendeskripsikan potensi buah belimbing di Agrowisata Belimbing Karangsari serta bagaimana kondisi perekonomian masyarakat setelah adanya agrowisata tersebut. Penelitian ini dilakukan untuk memperoleh gambaran mengenai faktor internal dan eksternal agrowisata serta untuk mengetahui strategi yang tepat dalam mengembangkan Agrowisata Belimbing Karangsari berdasarkan skala prioritas yang dihasilkan. Pendekatan studi kasus dipilih agar peneliti dapat mengetahui secara mendalam tentang Agrowisata Belimbing Karangsari, selain itu dengan menggunakan studi kasus maka penelitian akan lebih spesifik dan intensif.

Data yang digunakan adalah data primer dan sekunder yang diperoleh melalui kegiatan observasi, wawancara, dokumentasi dan kuisioner. Analisis data dalam penelitian ini meliputi: pengumpulan data, reduksi data, penyajia data, analisis lingkungan internal dan eksternal menggunakan matriks IFAS dan Matriks EFAS, untuk menentukan posisi menggunakan matriks IE, penyusunan strategi menggunakan matriks SWOT, serta matriks QSPM untuk memprioritaskan strategi. Pembobotan faktor serta strategi dilakukan oleh 7 responden yaitu 2 orang 
pengelola agrowisata, 1 orang dari LPMK, 2 orang pihak Dinas Pariwisata, serta 2 orang pihak kelurahan Karangsari.

\section{Hasil dan Diskusi}

\section{Indikator Pengembangan Agrowisata Belimbing Karangsari}

Ada empat indikator pengembangan pariwisata yang digunakan dalam penelitian ini yaitu :

1. Indikator SDA (Sumber Daya Alam) dan Lingkungan

Jumlah pohon belimbing di area agro ada 2000 pohon yang disewa oleh 50 orang petani. Pohon belimbing Agrowisata Belimbing Karangsari dirawat oleh para petani yang tergabung dalam Kelompok Tani Margo Mulyo yang dibina oleh Dinas Pariwisata Kota Blitar. Untuk menjaga keberlangsungan agrowisata ini, petani merawat pohonnya dengan cara yang ramah lingkungan. Petani meminimalisir penggunaan pupuk kimia, sebagian besar pupuk yang digunakan adalah pupuk organik yang berasal dari daun-daun belimbing yang rontok serta pupuk kandang.

2. Indikator SDM (Sumber Daya Manusia)

Agrowisata ini dikelola dengan konsep pemberdayaan masyarakat lokal dengan tujuan agar mereka dapat turut berperan dalam kegiatan pertanian dan kepariwisataan. Semua pihak pengelola agrowisata adalah waga Karangsari, sehingga program pemberdayaan ini dapat berjalan sesuai sasaran.

\section{Indikator Sarana dan Prasarana}

Kawasan Agrowisata Belimbing Karangsari didukung dengan dilaluinya jalan Kolektor Primer Kota Blitar serta lokasi yang dekat dengan terminal sehingga memudahkan akses menuju agrowisata. Selain itu kawasan ini juga sudah dilayani jaringan listrik berupa saluran SUTM dan SUTR untuk mendukung perkembangan prasarana di Agrowisata Belimbing Karangsari. Selain itu prasarana air minum juga telah tersedia dan terlayani, sudah tersedia 5 unit pompa air dan 1 unit SPAM untuk pengembangan Kawasan Agrowisata Belimbing Karangsari. Sistem drainase juga telah tersedia yang merupakan bagian dari drainase desa Karangsari dan menjadi satu dengan sistem pengairan untuk lahan/sawah di desa Karangsari. Fasilitas yang tersedia cukup memadahi, yaitu toilet, mushola, gazebo serta tempat parkir yang luas.Untuk upaya pelayanan yang diberikan pihak agrowisata yaitu menggunakan pedoman "suguh, gupuh, lungguh".

4. Indikator Pemasaran

Pemasaran yang dilakukan Agrowisata Belimbing Karangsari adalah melalui penyebaran brosur di hotel-hotel dan biro perjalanan yang ada di Kota Blitar. Selain itu Dinas Pariwisata juga turut berperan dalam mempromosikan melalui Jatim Travel Mart. Promosi secara online dilakukan melalui media social intagram dan facebook.

\section{Analisis Faktor Internal}

1. Memiliki lokasi yang luas

Agrowisata Belimbing Karangsari memiliki lokasi yang sangat luas, yaitu 5ha. Lahan yang luas ini dapat menampung banyak wisatawan dan dapat memicu wisatawan untuk datang bersama rombongan atau keluarga, serta masih ada lahan jika akan menambah fasilitas serta infrastruktur untuk mendukung perkembangan Agrowisata Belimbing Karangsari.

2. Memiliki kualitas buah yang unggul

Kualitas buah belimbing yang dihasilkan di Agrowisata Belimbing Karangsari merupakan varietas unggul yang telah disertifikasi oleh Kementrian Pertanian sebagai buah belimbing Karangsari Merah. Buah belimbing ini memiliki ciri khas yang membedakan dengan buah belimbing dari daerah lain, buahnya sangat besar, berwarna kuning kemerahan, memiliki kandungan air yang banyak serta rasanya sangat manis.

3. Adanya fasilitas pemandu wisata

Fasilitas pemandu wisata ini sangat membantu wisatawan untuk menuju lokasi kebun mengingat lokasi agro yang sangat luas. Fasilitas pemandu wisata ini bisa diperoleh tanpa tanpa tambahan biaya lagi.

4. Terdapat tempat pengolahan belimbing

$\mathrm{Di}$ area Agrowisata Belimbing Karangsari terdapat tempat pengolahan buah belimbing, jadi selain mendapat manfaat hiburan wisatawan juga mendapat manfaat edukasi dari proses pengolahan buah belimbing ini.

5. Lokasi strategis

Agrowisata Belimbing Karangsari memiliki lokasi yang strategis sekaligus mudah dijangkau karena berada di hampir tengah Kota Blitar serta berada dekat dengan 
terminal. Selain itu akses menuju agrowisata ini sangat mudah dilalui karena berada dipinggir jalan raya kolektor primer Kota Blitar, lokasi yang strategis akan memudahkan wisatawan untuk menjangkau agrowisata ini.

6. Petani memperhatikan kelestarian

Petani sangat memperhatikan kelestarian lingkungan dengan cara meminimalisir penggunaan pupuk kimia. Hal ini berarti para petani mendukung konsep pariwisata berkelanjutan.

7. Aspek sarana dan prasarana yang memadahi

Aspek sarana dan prasarana yang memadahi sangat penting dalam sebuah tempat pariwisata. Berdasarkan paparan data sebelumnya dapat disimpulkan bahwa dari segi sarana dan prasarana di Agrowisata cukup memadahi.

8. Kurangnya kebersihan kawasan

Menurut beberapa wisatawan yang datang ke Agrowisata Belimbing Karangsari kebersihan di area agro ini masih kurang, banyak daun dan ranting belimbing yang jatuh berserakan meskipun bukan sampah plastik tapi hal ini sangat mengganggu pemandangan dan terlihat kotor.

9. Mahalnya harga belimbing hasil petik sendiri

Setiap wisatawan yang datang dipersilahkan untuk memetik buah belimbing sendiri dan boleh dibawa pulang dengan harga Rp. 10.000 per kilo gram. Menurut beberapa wisatawan harga tersebut terlalu mahal karena satu kilo buah belimbing berukuran besar hanya berisi 2 buah saja, bahkan ada satu buah belimbing yang beratnya 1,5 kilo gram.

10. Kurangnya fasilitas utuk petik belimbing

Jumlah fasilitas petik belimbing (orok) yang disediakan di masing-masing kebun masih kurang, dalam satu kebun rata-rata hanya menyediakan 2 orok saja. Wisatawan yang akan memetik belimbing dalam satu kebun harus bergantian sehingga hal tersebut kurang efektif. Beberapa kebun ada yang menyediakan keranjang untuk mengumpulkan buah yang sudah dipetik, namun sebagian kebun tidak menyediakan sehingga wisatawan yang memetik buah cukup banyak akan kesulitan.
11. Kurangnya pengawasan terhadap lokasi wisata

Lokasi wisata ini juga kurang tertutup sehingga ada orang yang dapat memasuki lokasi wisata tidak melaui pintu masuk melainkan melalui akses lain dan bahkan berkendara dalam kebun yang dapat mengganggu wisatwan.

12. Belum ada penjual souvenir

Tempat perbelanjaan oleh-oleh dan souvenir dalam suatu tempat wisata sangatlah penting, mengingat sebagian besar wisatawan Agrowisata Belimbing Karangsari berasal dari luar kota, maka mereka pasti ingin membeli souvenir untuk oleh-oleh.

13. Promosi yang belum intensif

Promosi yang dilakukan oleh pihak pengelola Agrowisata Belimbing Karangsari masih belum efektif, hal ini dilihat dari segi promosi secara online melalui social media facebook dan instagram. Kedua akun social media tersebut kurang update dan kurang informatif dalam menyampaikan informasi. Serta belum tersedianya pemesanan tiket secara online.

\section{Analisis Faktor Eksternal}

1. Lokasi yang dekat dengan Makam Bung karno

Makam Bung Karno merupakan destinasi wisata utama di Kota Blitar, hal ini memberikan dampak positif kepada Agrowisata Belimbing Karangsari. Wisatawan yang datang ke Makam Bung Karno yang sebagian besar datang bersama rombongan berasal dari luar kota daripada langsung pulang begitu saja, mereka dapat berkunjung ke Agrowisata Belimbing Karangsari. Lokasi agro dan Makam Bung Karno yang tidak terlalu jauh merupakan peluang untuk menarik wisatawan.

2. Adanya dukungan dari pemerintah

Dalam pengembangan agrowisata ini banyak mendapat dukungan dari pemerintah, seperti Dinas Pariwisata yang memberikan sumbangan dana untuk membangun fasilitas serta membantu dalam mempromosikan. Dinas pertanian yang memberikan penyuluhan kepada petani tentang budidaya tanaman belimbing yang baik. Dikominfotik yang membantu menyeleksi warga yang akan mendaftar sebagai pengurus agrowisata. Dengan adanya dukungan dari pemerintah dapat memudahkan Agrowisata Belimbing Karangsari untuk lebih berkembang lago. 
3. Adanya bantuan promosi dari hotel dan biro perjalanan

Bantuan promosi dari hotel-hotel dan biro perjalanan melalui brosur merupakan suatu peluang bagi agrowisata ini untuk menarik wisatawan.

4. Adanya dukungan dari masyarakat

Agrowisata Belimbing Karangsari mendapat dukungan dari masyarakat hal ini terlihat dari banyaknya warga yang berantusias untuk menjadi pengurus agrowisata serta banyaknya warga yang berjualan oleh-oleh disekitar lokasi wisata. Selain itu masyarakat menunjukkan dukungannya dengan cara menunjukkan keramah tamahannya kepada wisatawan.

5. Kecenderungan masyarakat untuk berlibur diluar kota

Wisatawan yang berkunjung ke Agrowisata Belimbing Karangsari sebagian besar adalah rombongan yang berasal dari luar kota. Adanya kecenderungan masyarakat untuk berlibur diluar kota menjadi salah satu peluang untuk menarik minat wisatawan dari luar kota. Dengan adanya peluang tersebut maka akan menjadikan motivasi bagi pihak agrowisata untuk lebih mengembangkan dan memperbaiki fasilitasnya agar tidak mengecewakan wisatawan serta mampu bersaing dengan wisata-wisata lainnya.

6. Terkenalnya buah belimbing yang berasal dari Blitar

Blitar memang terkenal dengan buah belimbingnya, bahkan buah belimbing di supermarket seluruh Indonesia sebagian besar dipasok oleh buah belimbing dari Karangsari. Hal ini menjadi peluang bagi Agrowisata Belimbing Karangsari untuk menarik wisatawan baik dari dalam maupun luar kota melalui buah belimbingnya terkenal.

7. Buah belimbing kurang diminati
Berdasarkan hasil wawancara dari pengunjung, sebenarnya mereka kurang minat terhadap buah belimbing. Buah belimbing memang kurang populer daripada buah lain seperti strawberry, jeruk, apel dll. Hal ini merupakan ancaman bagi Agrowisata Belimbing Karangsari karena jika wisatawan yang berkunjung tidak minat terhadap buah belimbing maka kemungkinan kecil mereka akan datang lagi Agrowisata Belimbing Karangsari

8. Banyaknya bermunculan tempat wisata lain

Adanya tempat-tempat wisata baru merupakan ancaman bagi Agrowisata Belimbing Karangsari karena akan ada kecenderungan masyarakat untuk memilih tempat wisata lainnya yang mungkin lebig menarik.

9. Pohon belimbing hanya berbuah setahun tiga kali

Pohon belimbing tidak bisa berbuah berkali-kali, hanya 2 sampai 3 kali dalam satu tahun hal tersebut menjadi hambatan dan ancaman bagi Agrowisata Belimbing Karangsari. Kondisi tersebut menyebabkan wisatawan sulit mendapatkan buah belimbing di luar panen raya. Pernah suatu ketika rombongan wisatawan datang dan ternyata tidak ada pohon belimbing yang berbuah sehingga mengecewakan. Ketika tidak ada pohon belimbing yang berbuah maka agrowisata ditutup sampai pohon belimbing berbuah.

10. Adanya hama yang menyerang tanaman belimbing

Hama merupakan hambatan dan ancaman bagi petani belimbing dilokasi Agrowisata Belimbing Karangsari. Hama yang menyerang tanaman belimbing akan mengakibatkan buah belimbing rasanya tidak manis dan tidak dapat tumbuh besar.

\section{Matriks IFAS}

Berikut merupakan matriks IFAS yang terdiri dari kekuatan dan kelemahan pada faktor internal yang dapat mempengaruhi usaha pengembangan Agrowisata Belimbing Karangsari dalam rangka meningkatkan perekonomian masyarakat.

Tabel 2. Matriks IFAS (Internal Strategic Factors Summary)

\begin{tabular}{|c|c|c|c|c|c|}
\hline Kode & Faktor Internal & Jumlah & Bobot & Rating & Skor \\
\hline \multicolumn{6}{|c|}{ Kekuatan : } \\
\hline S1 & Lokasi yang luas & 21 & 0.07 & 3 & 0.21 \\
\hline S2 & Kualitas buah yang unggul & 27 & 0.09 & 4 & 0.36 \\
\hline S3 & Menyediakan fasilitas pemandu & 23 & 0.08 & 3 & 0.23 \\
\hline
\end{tabular}




\begin{tabular}{|c|c|c|c|c|c|}
\hline & wisata & & & & \\
\hline S4 & $\begin{array}{l}\text { Memiliki tempat pengolahan } \\
\text { belimbing }\end{array}$ & 26 & 0.09 & 4 & 0.34 \\
\hline S5 & Lokasi strategis & 27 & 0.09 & 4 & 0.36 \\
\hline S6 & $\begin{array}{l}\text { Petani memperhatikan kelestarian } \\
\text { Lingkungan }\end{array}$ & 24 & 0.08 & 3 & 0.24 \\
\hline S7 & $\begin{array}{l}\text { Aspek sarana dan prasarana yang } \\
\text { memadahi }\end{array}$ & 28 & 0.09 & 4 & 0.37 \\
\hline \multicolumn{5}{|c|}{$\begin{array}{r}\text { Total Skor Faktor Kekuatan } \\
\end{array}$} & 2.11 \\
\hline \multicolumn{6}{|c|}{ Kelemahan : } \\
\hline W1 & Kurangnya kebersihan & 23 & 0.08 & 3 & 0.23 \\
\hline W2 & Mahalnya harga belimbing & 23 & 0.08 & 3 & 0.23 \\
\hline W3 & $\begin{array}{l}\text { Kurangnya fasilitas untuk petik } \\
\text { buah }\end{array}$ & 22 & 0.07 & 3 & 0.22 \\
\hline W4 & $\begin{array}{l}\text { Kurangnya pengawasan di lokasi } \\
\text { wisata }\end{array}$ & 17 & 0.06 & 2 & 0.11 \\
\hline W5 & Belum ada penjual souvenir & 19 & 0.06 & 3 & 0.19 \\
\hline W6 & Promosi yang belum intensif & 22 & 0.07 & 3 & 0.22 \\
\hline \multicolumn{5}{|c|}{ Total Skor Faktor Kelemahan } & 1.20 \\
\hline & Total Skor IFAS & 302 & 1 & & 3.30 \\
\hline
\end{tabular}

\section{Sumber : Data Primer diolah, 2019}

Berdasarkan hasil perhitungan pada matriks IFAS (Internal Strategic Factors Summary) dapat diketahui bahwa yang menjadi kekuatan utama Agrowisata Belimbing Karangsari adalah aspek sarana dan prasarana yang memadahi dengan skor 0,37 . Faktor kekuatan lain yang medukung adalah kualitas buah yang unggul serta lokasi yang strategis dengan skor 0,36. Ketiga faktor tersebut memiliki pengaruh yang besar terhadap lingkungan internal agrowisata dalam usaha mengembangkan Agrowisata Belimbing Karangsari. Berdasarkan kriteria pembobotan, skor tersebut termasuk dalam kategori kurang berpengaruh, namun penting untuk diperhatikan.

\section{Matriks EFAS}

Berikut merupakan matriks EFAS yang terdiri dari peluang dan ancaman pada faktor eksternal yang dapat mempengaruhi pengembangan Agrowisata Belimbing Karangsari dalam rangka meningkatkan perekonomian masyarakat.

Tabel 3. Matriks EFAS (Eksternal Strategic Factors Summary)

\begin{tabular}{|c|c|c|c|c|c|}
\hline Kode & Faktor Eksternal & Jumlah & Bobot & Rating & Skor \\
\hline \multicolumn{6}{|c|}{ Peluang : } \\
\hline O1 & $\begin{array}{l}\text { Lokasi yang dekat dengan Makam } \\
\text { Bung Karno }\end{array}$ & 21 & 0.09 & 3 & 0.27 \\
\hline $\mathrm{O} 2$ & Dukungan dari pemerintah & 27 & 0.11 & 4 & 0.46 \\
\hline $\mathrm{O} 3$ & $\begin{array}{l}\text { Adanya bantuan promosi dari hotel } \\
\text { dan biro perjalanan }\end{array}$ & 24 & 0.10 & 3 & 0.30 \\
\hline $\mathrm{O} 4$ & Dukungan dari masyarakat & 25 & 0.11 & 4 & 0.42 \\
\hline O5 & $\begin{array}{l}\text { Kecenderungan masyarakat untuk } \\
\text { berlibur ke luar kota }\end{array}$ & 17 & 0.07 & 2 & 0.14 \\
\hline O6 & Terkenalnya buah belimbing yang & 27 & 0.11 & 4 & 0.46 \\
\hline
\end{tabular}




\begin{tabular}{|c|l|r|r|r|c|}
\hline & berasal dari Blitar & & & \\
\hline \multicolumn{7}{|c|}{ Total Skor Faktor Peluang } & 2.05 \\
\hline Ancaman : & 22 & 0.09 & 3 & 0.28 \\
\hline T1 & Buah belimbing kurang diminati & 22 & 0.09 & 3 & 0.28 \\
\hline T2 & Banyaknya pilihan tempat wisata lain & 28 & 0.12 & 4 & 0.47 \\
\hline T3 & $\begin{array}{l}\text { Pohon belimbing hanya berbuah 3 } \\
\text { tahun sekali }\end{array}$ & $\begin{array}{l}\text { Tdanya serangan hama pada tanaman } \\
\text { belimbing }\end{array}$ & 24 & 3 & 0.30 \\
\hline T4 & \multicolumn{7}{|c|}{ Total Skor Faktor Ancaman } & & 1.33 \\
\hline \multicolumn{7}{|c|}{ Total Skor EFAS } & 237 & 1 & & 3,38 \\
\hline
\end{tabular}

\section{Sumber : Data Primer diolah, 2019}

Berdasarkan hasil penghitungan matriks EFAS (Eksternal Strategic Factors Summary) dapat diketahui bahwa faktor peluang utama yang dapat dimanfaatkan oleh Agrowisata Belimbing Karangsari dan berdampak baik bagi pengembangan agrowisata tersebut adalah dukungan dari pemerintah dan terkenalnya buah belimbing yang berasal dari Blitar. Kedua faktor peluang tersebut memiliki skor sebesar 0,46. Dukungan dari pemerintah berupa bantuan promosi, bantuan dana serta dukungan lainnya yang diberikan akan mempermudah Agrowisata Belimbing Karangsari untuk mengembangkan potensi pariwisatanya. Terkenalnya buah belimbing yang berasal drai Blitar juga merupakan suatu peluang untuk menarik minat wisatawan untuk datang ke Agrowisata Belimbing Karangsari.

\section{Matriks IE}

Matriks IE diperoleh melalui penggabungan informasi yang dihasilkan dari matriks IFAS dan matriks EFAS untuk mendapatkan informasi mengenai posisi Agrowisata Belimbing Karangsari dalam perkembangannya. Matriks IE digunakan untuk menentukan posisi agrowisata dengan cara mencari selisih matriks IFAS yaitu selisih antara bobot faktor kekuatan dan kelemahan yang akan menjadi titik koordinat sumbu $x$ dan selisih pada matriks EFAS dapat ditentukan dengan cara mencari selisih bobot faktor peluang dan ancaman yang nilainya akan menentukan titik koordinat di sumbu $y$. Dengan mengetahui posisi agrowisata maka dapat menyusun dan menentukan strategi yang tepat.

\section{Gambar 1. Matriks IE}

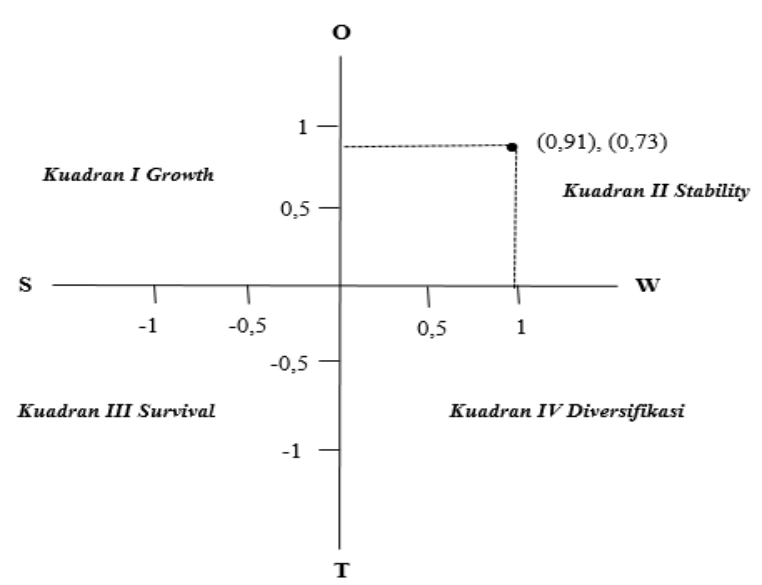

Sumber: Data Primer, diolah 2019

Berdasarkan hasil pengolahan data pada matriks IE menunjukkan bahwa sumbu $x$ berada dititik 0,91 yang merupakan selisih dari faktor kekuatan dan kelemahan serta sumbu $y$ berada dititik 0,73 yang merupakan selisih dari faktor peluang dan ancaman. Kedua titik tersebut menjadikanan posisi Agrowisata Belimbing Karangsari berada dalam kuadran II atau, dalam kondisi ini strategi yang tepat untuk dikembangkan adalah strategi stabity. Menurut Rangkuti (2008) strategi stabilitas diarahkan untuk 
mempertahankan suatu keadaan dengan berupaya memanfaatkan peluang.

\section{Analisis SWOT}

Tujuan dari matriks SWOT dalam penelitian ini adalah untuk mengumpulkan sebanyak mungkin strategi yang dapat digunakan dalam usaha pengembangan Agrowisata Belimbing Karangsari. Pemilihan strategi utama pada matriks SWOT disesuaikan dengan posisis agrowisata pada matriks IE yang telah dibuat sebelumnya. Berdasarkan hasil analisis matriks SWOT pada Agrowisata Belimbing Karangsari, diperoleh 14 alternatif strategi yang terdiri dari dua alternatif strategi SO, lima alternatif strategi WO, empat alternatif strategi ST, dan tiga alternatif strategi WT.

Tabel 4. Matriks SWOT

\begin{tabular}{|c|c|c|}
\hline EFAS & $\begin{array}{l}\text { STRENGTHS (S) } \\
\text { 1. Lokasi yang luas } \\
\text { 2. Kualitas buah yang } \\
\text { unggul } \\
\text { 3. Menyediakan fasilitas } \\
\text { pemandu wisata } \\
\text { 4. Memiliki tempat } \\
\text { pengolahan belimbing } \\
\text { 5. Lokasi strategis } \\
\text { 6. Petani memperhatikan } \\
\text { kelestarian lingkungan } \\
\text { 7. Sarana dan prasarana } \\
\text { yang memadahi }\end{array}$ & $\begin{array}{l}\text { WEAKNESSES }(\mathbf{W}) \\
\text { 1. Kurangnya kebersihan } \\
\text { 2. Mahalnya harga belimbing } \\
\text { 3. Kurangnya fasilitas untuk } \\
\text { petik buah } \\
\text { 4. Kurangnya pengawasan di } \\
\text { lokasi wisata } \\
\text { 5. Belum ada penjual souvenir } \\
\text { 6. Promosi yang belum intensif }\end{array}$ \\
\hline $\begin{array}{l}\text { OPPORTUNITIES (O) } \\
\text { 1. Lokasi yang dekat } \\
\text { dengan Makam Bung } \\
\text { Karno } \\
\text { 2. Dukungan dari } \\
\text { pemerintah } \\
\text { 3. Bantuan promosi dari } \\
\text { hotel dan biro perjalanan } \\
\text { 4. Dukungan dari } \\
\text { masyarakat } \\
\text { 5. Kecenderungan } \\
\text { masyarakat untuk } \\
\text { berlibur ke luar kota } \\
\text { 6. Terkenalnya buah } \\
\text { belimbing yang berasal } \\
\text { dari Blitar }\end{array}$ & $\begin{array}{l}\text { STRATEGI SO } \\
\text { 1.Menyediakan paket } \\
\text { wisata yang menarik (S1, } \\
\text { S2, S3, S4, S5, S6, S7, } \\
\text { O3, O5, O6) } \\
\text { 2.Menambah fasilitas } \\
\text { penginapan agar dapat } \\
\text { menerima wisatawan } \\
\text { yang lebih dan bisa } \\
\text { tinggal lebih lama (S1, } \\
\text { S7, O1, O2, O3, O4, O5) }\end{array}$ & $\begin{array}{l}\text { STRATEGI WO } \\
\text { 1. Menambah pekerja } \\
\text { masyarakat sekitar sebagai } \\
\text { petugas kebersihan (W1, O4) } \\
\text { 2. Memasang pamflet di sekitar } \\
\text { jalan utama menuju Makam } \\
\text { Bung Karno untuk } \\
\text { mempromosikan agrowisata } \\
\text { (W6, O1, O2, O3, O6,) } \\
\text { 3. Menambah fasilitas agar } \\
\text { sebanding dengan harga } \\
\text { belimbing (W2, W3, O2, O5, } \\
\text { O6) } \\
\text { 4. Memberdayakan masyarakat } \\
\text { untuk membuat souvenir } \\
\text { (W5, O2, O4, O5, O6) } \\
\text { 5. Bekerjasama dengan warga } \\
\text { setempat untuk saling } \\
\text { menjaga kenyamanan } \\
\text { pengunjung (W4, O4, O5) }\end{array}$ \\
\hline
\end{tabular}




\begin{tabular}{|c|c|c|}
\hline TREATHS (T) & STRATEGI ST & STRATEGI WT \\
\hline $\begin{array}{l}\text { 1. Buah belimbing kurang } \\
\text { diminati } \\
\text { 2. Banyaknya pilihan } \\
\text { tempat wisata lain } \\
\text { 3. Pohon belimbing hanya } \\
\text { berbuah } 3 \text { tahun sekali } \\
\text { 4. Adanya serangan hama } \\
\text { pada tanaman }\end{array}$ & $\begin{array}{l}\text { 1. Mempromosikan } \\
\text { agrowisata dengan cara } \\
\text { yang informatif melalui } \\
\text { media online serta } \\
\text { memberikan edukasi } \\
\text { tentang manfaat buah } \\
\text { belimbing (S1, S2, S4, } \\
\text { S5, S6, S7, T1, T2) } \\
\text { 2. Melakukan kerjasama } \\
\text { dengan Dinas Pertanian } \\
\text { untuk memberdayakan } \\
\text { masyarakat } \\
\text { menggunakan bahan } \\
\text { ramah lingkungan untuk } \\
\text { mengusir hama (S6, T4) } \\
\text { 3. Mengoptimalkan peran } \\
\text { pemandu wisata dengan } \\
\text { cara memberikan } \\
\text { layanan yang informatif } \\
\text { dan memuaskan (S2, S3, } \\
\text { S4, T1, T2) } \\
\text { 4. Membuka kebun milik } \\
\text { warga sebagai tambahan } \\
\text { wisata petik buah (S5, } \\
\text { T3) }\end{array}$ & $\begin{array}{l}\text { 1. Menyediakan fasilitas petik } \\
\text { buah yang memadahi agar } \\
\text { dapat bersaing dengan tempat } \\
\text { wisata lain (W1, W2, W3, } \\
\text { W4, W5, T2) } \\
\text { 2. Melakukan kerja sama } \\
\text { dengan tempat wisata lain } \\
\text { agar dapat membuat paket } \\
\text { yang berbeda atau membuat } \\
\text { paket wisata bersama (W6, } \\
\text { T1, T2) } \\
\text { 3. Mengoptimalkan promosi dan } \\
\text { menggunakan media online } \\
\text { untuk pemesanan tiket agar } \\
\text { dapat memperkirakan jumlah } \\
\text { buah yang siap petik dan } \\
\text { jumlah wisatawan yang akan } \\
\text { berkunjung (W6, T3) }\end{array}$ \\
\hline
\end{tabular}

\section{Sumber : Data Primer, Diolah 2019}

\section{Analisis QSPM}

Berdasarkan hasil analisis matriks QSPM Agrowisata Belimbing Karangsari (lampiran 3), diketahui bahwa alternative strategi yang paing diprioritakan adalah strategi yang memiliki TAS (Total Attractiveness Score) tertinggi. Berikut adalah alternatif strategi yang diurutkan berdasarkan penjumlahan total nilai daya tarik:

1. Menyediakan fasilitas petik buah yang memadahi agar dapat bersaing dengan tempat wisata lain

2. Memasang pamflet di sekitar jalan utama menuju Makam Bung Karno untuk mempromosikan agrowisata

3. Membuka kebun milik warga sebagai tambahan wisata petik buah

4. Melakukan kerja sama dengan tempat wisata lain agar dapat membuat paket yang berbeda atau membuat paket wisata bersama

5. Menambah fasilitas agar sebanding dengan harga belimbing

6. Menyediakan paket wisata yang menarik
7. Menyediakan fasilitas petik buah yang memadahi agar dapat bersaing dengan tempat wisata lain

8. Mengoptimalkan peran pemandu wisata dengan cara memberikan layanan yang informatif dan memuaskan

9. Mengoptimalkan promosi dan menggunakan media online untuk pemesanan tiket agar dapat memperkirakan jumlah buah yang siap petik dan jumlah wisatawan yang akan berkunjung

10. Melakukan kerjasama dengan Dinas Pertanian untuk memberdayakan masyarakat menggunakan bahan ramah lingkungan untuk mengusir hama

11. Bekerjasama dengan warga setempat untuk saling menjaga kenyamanan pengunjung

12. Mempromosikan agrowisata dengan cara yang informatif melalui media online serta memberikan edukasi tentang manfaat buah belimbing

13. Menambah pekerja masyarakat sekitar sebagai petugas kebersihan 
14. Memberdayakan masyarakat untuk membuat souvenir

Berdasarkan hasil analisis QSPM alternatif strategi yang memiliki total nilai daya tarik (TAS) tertinggi adalah menyediakan fasilitas petik buah yang memadahi agar dapat bersaing dengan tempat wisata lain yaitu sebesar 5,98. Strategi tersebut adalah strategi yang paling diprioritaskan daripada strategi yang lain. Mengingat objek yang ditawarkan adalah buah belimbing maka fasilitas petik buah seperti keranjang buah dan alat petik (orok) harus memadahi, memadahi dalam hal ini adalah dari segi kuantitas. Apabila fasilitas petik buah sudah memadahi, maka dapat melakukan strategi selanjutnya.

Alternatif strategi kedua yaitu memasang pamflet di sekitar jalan utama menuju Makam Bung Karno untuk mempromosikan agrowisata. Strategi ini memiliki nilai TAS yang cukup tinggi yaitu sebesar 5,85. Nilai TAS pada strategi ini yang cukup tinggi karena merupakan strategi yang efektif untuk melakukan promosi dengan memanfaatkan peluang dari Makam Bung Karno Blitar.

\section{Kesimpulan}

Berdasarkan hasil analisis dan pembahasan pada penelitian ini maka kesimpulan yang dapat diambil sesuai dengan tujuan penelitian adalah sebagai berikut:

1. Berdasarkan hasil analisis matriks IFAS yang menjadi kekuatan utama Agrowisata Belimbing Karangsari adalah aspek sarana dan prasarana yang menadahi selain itu kualitas buah yang unggul serta lokasi yang strategis juga menjadi faktor pendukung kekuatan utama. Sedangkan kelemahan utamanya adalah kurangnya kebersihan dan mahalnya harga belimbing. Hasil matriks IFAS menunjukkan bahwa total skor IFAS sebesar 3,30 yang menunjukkan bahwa kondisi lingkungan internal yang mempengaruhi Agrowisata
Promosi yang gencar dan efektif akan mempengaruhi jumlah wisatawan yang akan berkunjung, oleh karena itu strategi ini penting untuk dilakukan.

Penerapan prioritas kedua strategi tersebut sangat cocok, karena kedua strategi tersebut saling berkaitan antara ketersediaan fasilitas yang memadahi dengan promosi wisata. Ketika fasilitas petik buah yang merupakan aspek internal sudah memadahi maka sudah patut untuk dipromosikan. Karena apabila fasilitas dari aspek internal belum memadahi dan sudah melakukan promosi maka akan mengecewakan wisatawan yang berkunjung. Kedua strategi tersebut penting untuk dilakukan dalam usaha untuk meningkatkan jumlah wisatawan yang berkunjung. Ketika jumlah wisatawan yang berkunjung meningkat maka pendapatan petani juga akan meningkat dari hasil penjualan buah belimbingnya. Tidak hanya petani tetapi para pedagang oleh-oleh juga akan meningkat penghasilannya. Dengan terus berkembangnya Agowisata Belimbing Karangsari maka siklus perekonomian masyarakat dapat terus berjalan.

Belimbing Karangsari berada dalam kondisi kuat atau diatas rata-rata.

Analisis EFAS menunjukkan bahwa yang menjadi peluang utama dalam mengembangkan Agrowisata Belimbing Karangsari adalah dukungan dari pemerintah dan terkenalnya buah belimbing yang berasal dari Blitar. Sedangkan yang menjadi ancaman utamanya adalah pohon belimbing yang hanya berbuah 3 tahun sekali. Total skor matriks EFAS adalah sebesar 3,38 hal ini menunjukkan bahwa kondisi lingkungan eksternal yang mempengaruhi pengembangan Agrowisata Belimbing Karangsari dalam kondisi baik, karena peluang usaha yang dimiliki dapat mengatasi ancaman yang ada. 
2. Hasil perhitungan pada matrilks IE menunjukkan bahwa posisi Agrowisata Belimbing Karangsari berada pada kuadran II, dalam kondisi ini strategi yang tepat untuk dikembangkan adalah strategi stabity. Alternatif strategi yang dihasilkan dari analisis SWOT ada 14 strategi yaitu SO1, SO2, WO1, WO2, WO3, WO4, WO5, ST1, ST2, ST3, ST4, WT1, WT2, dan WT3. Berdasarkan analisis QSPM strategi yang menjadi prioritas

\section{References}

[1] Anindita M. 2015. Analisis FaktorFaktor yang Mempengaruhi Tingkat Kunjungan ke Kolam Renang Boja, (online), (http://eprints.undip.ac.id/45445/1/15_A NINDITA.pdf), diakses 23 September 2018

[2] Arsyad, Lincolin. 2002. Pengantar Perencanaan Ekonomi Daerah, Edisi Kedua, BPFE UGM, Yogyakarta.

[3] Atahena \& Utama . 2015. Faktor-Faktor yang Menentukan Wisatawan Berkunjung ke Taman Nasional Komodo di Kabupaten Manggarai Barat Nusa Tenggara Timur. (online), (https://jurnal.undhirabali.ac.id/index.ph p/pariwisata/article/view/13), diakses 23 September 2018

[4] Badan Pusat Statistika. 2016. Dampak Pariwisata Terhadap PDB Menurut Sektor Tahun 2016, (online)

[5] Badan Pusat Statistika. 2017. Kota Blitar dalam Angka 2017, (online), (https://blitarkota.bps.go.id/publication/ download.html), diakses 23 September 2018.

[6] Budiarti, S. D. 2013. Pengembangan Agrowisata Berbasis Masyarakat Pada Usahatani Terpadu Guna Meningkatkan Kesejahteraan Petani dan Keberlanjutan Sistem Pertanian Indonesia, Vol 18, No 3. Journal.ipb.ac.id, diakses tanggal 15 Oktober 2018.

[7] Effendi, Tenaya dan Sudarma. 2015. Pengembangan Agrowisata Pesuteraan utama adalah menyediakan fasilitas petik buah yang memadahi agar dapat bersaing dengan tempat wisata lain, sedangkan alternatif keduanya adalah memasang pamflet di sekitar jalan utama menuju Makam Bung Karno untuk mempromosikan agrowisata. Kedua alternatif strategi yang diprioritaskan tersebut dapat dipertimbangkan oleh pihak terkait dalam upaya pengembangan Agrowisata Belimbing Karangsari.

Alam Sutera Sari Segara di Desa Sibangkaja, Kecamatan Abisemal. Jurnal Vol 3, No 2.

[8] Ernaldi. 2010. Analisis Strategi Pengembangan Agrowisaata Perkebunan Teh Gunung Mas PTPN VIII Bogor Jawa Barat. Skripsi Departemen Agribisnis Institut Pertanian Bogor, diakses tanggal 12 Oktober 2018

[9] Kementerian Pariwista. Neraca Satelit Pariwisata Nasional 2017 (Nesparnas). Deputi Bidang Kelembagaan Kepariwisataan Kementerian Pariwisata 2017

[10] Palit, Talumingan dan Rumagit. 2017. Strategi Pengembangan Kawasan Agrowisata Rurukan. Jurnal Vol 13, No 2A.ejournal.unsrat.ac.id, diakses tanggal 15 Oktober 2018.

[11] Rangkuti F. 2008. Analisis SWOT: Teknik Membedah Kasus Bisnis Riorientasi Konsep Perencanaan Strategis Untuk Menghadapi Abad 21, Jakarta, PT Gramedia Pustaka Utama.

[12] Rinawati, R. 2014. Strategi Pengembangan Agrowisata Perkebunan Gunung Mas PTPN VIII. Jurnal Vol I (4): 18-27. Diakses tanggal 12 Oktober 2018

[13] Undang-Undang No. 10 Tahun 2009 tentang Kepariwisataan, (online), (https://www.ekowisata.org/uploads/file s/UU_10_2009.pdf), diakses 22 September 2018. 